\title{
Assessing the Potential Toward Open Educational Practices in Kyrgyzstan
}

\author{
Anita R Walz \\ Virginia Tech (USA) \\ arwalz@vt.edu \\ Jyldyz Bekbalaeva \\ American University of Central Asia (Kyrgyzstan) \\ bekbalaeva_j@auca.kg
}

\begin{abstract}
The study was undertaken to understand the propensity for increased engagement with open educational practices (OEP), to include methods prioritizing student-centered teaching \& learning, and awareness, use, and development of open educational resources (OER) among higher education faculty in Kyrgyzstan. The study employed a mixed-methods research design, combining qualitative and quantitative data obtained from 35 faculty, librarians, and administrators in institutions of higher education in Kyrgyzstan. This study aimed to identify current teaching practices and learning resource usage practices, gauge levels of knowledge regarding Kyrgyzstan's Copyright law, Creative Commons licenses, and Open Educational Resources, and investigate perceptions regarding potential roles for libraries in enabling others' learning regarding Copyright and Creative Commons, and open educational resources. Analysis of the results revealed a higher than expected gravitation toward student-centered pedagogy than previously assumed. The study also identified broad use of digital downloads as learning materials, conflation of open educational resources with free online resources, and positive perceptions of libraries' potential to instruct regarding Kyrgyz copyright, Creative Commons, and open educational resources, and needs for further professional development training for librarians.
\end{abstract}

Keywords: Open Educational Practices; Open Educational Resources; Teaching \& Learning; Kyrgyzstan

\section{Introduction}

The higher education system of Kyrgyz Republic has been going through multiple transformations at structural and institutional levels since the country gained its independence in 1991. Kyrgyzstan was introduced to open educational resources (OER) in early 2000. The OER initiative launched by the Ministry of Education and Soros-Kyrgyzstan Foundation has now reached many partners across educational institutions. Many of the projects are implemented at institutional level and aim to educate people on OER and to provide training on OER adoption and implementation. OER and other open educational practices (OEP), open pedagogy in particular, show promise in addressing shortages and aging of educational materials and in the transition from teacher/expert Soviet-era style pedagogy to deeper and more open learning practices.

We undertook this research in part to determine to what degree Soviet-era teaching practices are still prevalent in higher education, with the understanding that current practices may assist or work against implementation of open educational practices in Kyrgyzstan. The survey aimed to assess the potential for further adoption of open educational practices within higher education and focused on identifying baseline information regarding aspirational and reported teaching styles and practices, curriculum materials currently in use and their origin, level of awareness regarding Open 
Educational Resources, Creative Commons licenses, and Kyrgyz Copyright law, and perceptions regarding the potential role of academic libraries in providing instruction on Copyright, Creative Commons, and OER.

\section{First and Second Phases of Open}

Open Educational Resources (OER) are considered one of the most important educational innovations in the new millennium. Having emerged in early 2000's, the OER movement has grown considerably in the past decade to a global network of educational institutions, individuals and organizations that promote openness, collaboration, innovation and collective development and use of open educational materials (Butcher, 2011; Open Education Consortium, 2017).

The term OER refers to educational content in different formats that is openly licensed and available for use and re-use by students and educators. OER are subject to the litmus test of the 5 Rs: Retain, Reuse, Revise, Remix, and Redistribute (Wiley, n.d.). The central idea behind the concept of OER implies that the world's knowledge is a public good and that technology provides unprecedented opportunities for people to share and to use that knowledge (Smith \& Casserly, 2006).

Open Educational Practices (OEP) are a second phase of open, which include but go beyond access, availability, and creation of OER course material (DeRosa \& Jhangiani, 2017) to "improve learning experiences and innovate educational scenarios" (Ehlers, 2011). OEP venture into open learning architectures beyond University walls, into "open pedagogy." Open pedagogy is defined as "OER-enabled pedagogy" -- pedagogical practices reliant on OER (Wiley, 2017), or "open pedagogy" which as an "access-oriented commitment to learner-driven education AND as a process of designing architectures and using tools for learning that enable students to shape the public knowledge commons of which they are a part" (DeRosa \& Jhangiani, 2017). Student creation of non-disposable assignments that can be shared with the world fit nicely here (Hendricks, 2015). The second definition embeds a social justice commitment, understanding that access and creation of knowledge artifacts should be democratic, not limited to an elite or privileged group. Such an emphasis harkens back to the late 1970s when Canadian Claude Paquette outlined three sets of foundational values of open pedagogy as: autonomy and interdependence; freedom and responsibility; and democracy and participation, which essentially define "open" as being "very much about learner choice" (Morgan, 2016). Both of these definitions of "open pedagogy" can be complementary to OER, but are noticeably more focused on educational processes rather than informational content or artifacts created, consumed, or adapted in the process of learning. Existing learning theories and practices of constructivism and experiential learning have significant overlap with both OER-enabled pedagogy, and open/ learner-centric pedagogy.

While not all scholars agree that new pedagogies are required in order to realize the potential of open educational resources, aspects of open practices may be selected to amplify existing pedagogic practices (Masterman, 2015). Open educational practices incorporate or the same intent and many of the same practices as student-centered learning, whose primary goal is fostering deep learning and understanding as facilitated by deep approaches to learning. Open advocates link increasingly student-centered pedagogy to improved student outcomes as a part of a more "open" teaching process (Huitt \& Monnetti, 2017). In contrast, surface approaches are described as having a "reproducing orientation and extrinsic motivation and a fear of failure which is accompanied with rote memorisation and a narrow-syllabus bound attitude" (Baeten, Kyndt, Struyven \& Dochy, 2010). Open pedagogy, while varied in types of practices, is much the opposite and asks students to engage in 
"creating," shaping outcomes, utilizing agency, and the instructor acting as coach. As DeRosa and Jhangiani (2017) summarize:

...we might think of Open Pedagogy as an access-oriented commitment to learner-driven education AND as a process of designing architectures and using tools for learning that enable students to shape the public knowledge commons of which they are a part. We might insist on the centrality of the 5 Rs to this work, and we might foreground the investment that that Open Pedagogy shares with other learner-centered approaches to education (n.p.).

Baeten et al. (2010) analyzed over 100 studies in which teaching methods emphasized "student responsibility and activity in learning" and "a coaching role of the teacher". Many of the findings of Baeten's article mirror concerns the authors have regarding student (and instructor) perpetuation of surface or rote learning approaches rather than moving toward deep learning approaches. While admittedly complex, Baeten's review found that a teacher's orientation toward students plays a role regarding student adoption of deep or shallow learning practices. Students of teachers that are more involved and willing to change their conceptions are more likely to adopt deep approaches to learning. Students are likewise influenced by their perceptions of the course: Courses with an orientation toward students, including options for independent study influence students to take deeper learning approaches. Student confidence in their teacher's teaching, such as "answering students' questions, giving feedback, structuring the course, providing materials and illustrating lectures" also lend themselves to student adoption of deep learning practices. Relevance of activities to the student's future professional practice bode well for students opting for deeper learning engagement. These practices bode well as deep learning approaches. The 5Rs (retain, reuse, revise, remix, and redistribute) bode well as an ethical orientation toward knowledge sharing. Student skill in adopting and developing appropriate forms that fit the function of information they are developing and working is an important part of their learning. To the degree that instructors are supported and adhere to best practices for stimulating student engagement in deeper learning practices, increasingly diverse students may learn and understand in ways that are more transformative.

\section{The Kyrgyz Context}

The educational system of Kyrgyz Republic has been going through multiple transformations at both structural and institutional levels since the country gained its independence in 1991. Currently, more than 50 institutions of higher education offer bachelor's and master's degrees, as well as specialist's degrees comprising five years of training. While the academic programs are developed within the framework of the national educational standards, universities have a high degree of autonomy in defining their teaching methods and adopting educational technologies and innovations (European Commission, 2012). Given donor agendas, higher education institutions struggle with self-determination and whether internationalization serves the mission of transformative education in and for Kyrgyzstan (Merrill, 2011). Educational policy aside, we posit that a move to more studentcentred learning may aid Kyrgyz administrators, faculty and students in developing quality rubrics, and specifically Kyrgyz approaches to education which are relevant to the Kyrgyz context rather than those imported by a funder.

The Kyrgyz Republic's Ministry of Education sets licensing requirements for educational institutions. At every level, including Higher Education, the Ministry requires institutions to provide learning materials (e.g., textbooks, etc.) for students rather than students purchasing these themselves. The concept of OER also aligns with the vision of the Kyrgyz Republic's Ministry of Education, which placed "providing conditions for continuous education throughout life" among its key priorities 
(Strategy for Development, 2012). OER was first brought to attention of the academic community via occasional initiatives by education advocates in the early 2000's. One of the initial efforts to present OER countrywide was undertaken by the U.S. Embassy in 2008 with a series of events introducing Open Yale Courses at major universities in the capital city and one of the major cities in the Southern region (“V Oshe sostoyalas'”, 2008). In 2007-2008, the Library and Information Consortium of Kyrgyzstan initiated several projects related to open access and open repositories, trying to bring attention to open educational practices. However, OER had not come into focus until 2014, when the inaugural international conference Open Educational Resources (OER) and Digital Education brought together the government, public sector, educational practitioners and international experts to discuss the advancement of open education and free access to knowledge in the countries of Central Asia and Mongolia (OER Impact Map, 2014). The OER initiative launched by the Ministry of Education and Soros-Kyrgyzstan Foundation has now reached many partners across educational institutions. Many of the projects are implemented at institutional level and aim to educate people on OER and to provide training on OER adoption and implementation. These initiatives include launch of digital repositories of open educational materials, OER awareness campaigns (KyrlibNet), panel discussion (AUCA News, 2017), summer camps for educators (Soros Kyrgyzstan Foundation, 2017), and grant programs to support OER implementation (Soros, 2017). Some of these efforts have branched into open educational practices and open pedagogy, for example training in Wikipedia Editing at OER Summer Camps and remix of openly licensed Sociology course material at AUCA in Fall 2017. However, few developments focusing on policy development have taken place at the national level.

In spring 2017 the country had a major copyright reform, resulting in the amendments in the Intellectual Property Right Law, which mandates publicly funded educational resources to be publicly available (State Service Intellectual Property and Innovation, 2017). The legislation also has provisions on referring to fair use for educational purposes and facilitates the use of open licenses by creators and authors of works. The document also implements provisions of the Marrakesh Treaty, which the country acceded to the same year. This international copyright treaty, administered by World Intellectual Property Organization (WIPO, n.d.), has a clear humanitarian and social dimension and aims to facilitate access across national borders to print works by the blind, visually impaired or otherwise print-disabled persons through creating a set of mandatory limitations and exceptions. The treaty allows the libraries in the participating countries to provide and exchange accessible formats, such as Braille, audio, and large print across national borders (WIPO, 2017; EIFL, 2017). The Kyrgyz Republic's copyright reform has been recognized a significant step that will allow further policy development in the sphere of copyright, digital rights and Creative Commons licensing.

Policy developments aside, concerns remain. Though at least six institutions of higher education were established after independence, concern remains regarding instructional practices and program based reforms which lack clear academic outcomes. Because of a lack of other career options, more students than ever are attending University. Institutions which under the Soviet regime led diploma holders to specific jobs now produce students with diplomas who are on their own to find a use for the skills they may have developed. Some institutions are willing to grant a diploma after four or five years regardless of academic or professional quality indicators. (DeYoung, 2013). Universities lack placement centers or services, and a large number of students find work competing with their studies.

Economics aside, teacher/expert and passive-student pedagogies persist (DeYoung, 2008). The primary instructional mode during the Soviet-era was to receive texts from Moscow, lecture from the 
texts, and require students to repeat or recall information (DeYoung, 2013). As recently as 2016, research at one institution indicated that teaching styles suggested by the Kyrgyz education system are "very old, outdated, left from the former Soviet System". Further exacerbating factors included a reported lack of in-service training and shortage of instructional materials (Muhametjanova \& Cagiltay, 2016). In a theoretical study, de la Sablonnière, Taylor and Sadykova (2009) posit that the current normative teacher/expert methods create problems for the promotion of a studentcentered approach in Kyrgyzstan. Believing that there is promise because of government reforms and international attention, de la Sablonnière et al. (2009) argue that Kyrgyzstan could be a model example of a successfully implemented reform for other countries facing like challenges. She posits that instructors would need to change their roles by developing ways to measure competence, elicit interaction with students during lectures, consider students' prior knowledge, and learn to guide student learning. Similarly, students would need to become more active in the learning process. There is a role also for institutions: Instructors who wish to move from a teacher/expert to a student centered approach need assurances of job stability, resources, and support. de la Sablonnière et al. (2009) suggest that vocal minority of practitioners may cause others to question their current adherence to instructor-centric pedagogy, and that creative change may result -- if there is a clear articulation regarding teaching methods, a free exchange of ideas and experiences, collaboration between institutions, access to information resources, and support from the Ministries of education and international organizations (de la Sablonnière et al., 2009).

In this context of hoped-for change, expert/teacher Soviet-era pedagogy is a barrier to studentcentric open educational practices, deeper learning approaches, and likely to more creative and meaningful technology-rich learning. Continued adherence to traditional Soviet era teaching styles may decrease the fruition of open educational practices to arrive at their full potential.

\section{Gaps in the Literature}

Having been introduced in the early 2000s, OER is a relatively new phenomenon in Kyrgyzstan. Introduction of the term OEP is even newer. There is limited domestic research on educational developments in Kyrgyzstan and a significant lack of research on open educational resources or practices. The study is an attempt to fill in this gap. There is a need to identify the current state of awareness of OER and current teaching practices as these and other factors help to evaluate the propensity adoption of OEP by instructors and higher educational institutions. The study aims to identify the shift in the current teaching and learning practices, knowledge of OER, open licensing, related concepts of copyright, and perceptions regarding potential roles of libraries in educating others on these topics.

The majority of past research documents have been developed in the form of reports providing overview of the structure, developments and recommendations. The potential for OER in the Post-Soviet context was studied by the UNESCO's Institute for Information Technologies in Education attempting to analyze the use of information communication technologies (ICTs) in education and perspectives for the development of OER in former Soviet bloc countries. While there are many online resources developed and shared by educational institutions, most of them do not fall under the definition of OER as "teaching, learning and research materials, that reside in the public domains and have been released under open licenses that permit use, repurpose and reuse by others" (UNESCO, 2011).

Earlier efforts to obtain fragmentary survey data on OER were undertaken by the Association of Electronic Libraries in 2014-2015 within the framework of the countrywide OER awareness campaign. The KyrLibNet team conducted information and training sessions at major universities 
of the country, highlighting topics such as OER, types of OER, OER advantages and limitations, and introduction to Creative Commons Licenses. A brief survey was conducted at each training site to identify potential barriers in the use and adoption of OER. Respondents consisting of faculty, librarians, students, graduate and doctoral students and researchers identified several factors preventing successful development and use of OER. Preference of print format over electronic was named one of the barriers in the adopting OER, which is mostly available in digital formats. Other factors included lack of general awareness of OER, lack of technology skills, perception of time and efforts needed to be invested in order to find and to evaluate suitable OER, concerns about copyright infringements and lack of motivation and institutional support. (KyrLibNet, 2017). These findings were consistent with the barriers in the OER adoption in non-English speaking countries defined by UNESCO Institute for Information Technologies in Education (UNESCO, 2011).

Very little is known about instructor awareness of OER vs. "free online" resources. In a recent study on propensity for technology adoption, Muhametjanova cites familiarity with MIT's OCW (Open CourseWare), a portal of openly licensed content, and proposes this as a tool to be shared by all universities in Kyrgyzstan (Muhametjanova \& Cagiltay, 2016).

Further research on student -as well as Administrator- perceptions and aspirations is warranted, but are not part of this study.

\section{Survey Research}

\section{Research Intent and Scope}

One hundred and twenty faculty, administrators, and librarians employed in institutions of higher education in Kyrgyzstan were invited to respond to a mixed methods electronic survey available in English and Russian (see appendix). The survey was distributed to faculty via librarians on the Kyrgyz Library and Information Consortium email list, a university all-faculty mailing list, and through the Kyrgyz Open Education group email list which consists of librarians, faculty, and academic staff from universities across Kyrgyzstan. The survey was sent three times during a one-month period. The survey aimed to assess the potential for further adoption of open educational practices within higher education and focused on identifying baseline information regarding aspirational and reported teaching styles and practices, curriculum materials currently in use and their origin, level of awareness regarding Open Educational Resources, Creative Commons licenses, and Kyrgyz Copyright law, and perceptions regarding the potential role of academic libraries in providing instruction on Copyright, Creative Commons, and OER.

\section{Research Questions}

1 What curriculum resources are higher education faculty in Kyrgyzstan currently using?

2 What teaching methods/pedagogies are higher education faculty in Kyrgyzstan currently using?

3 What is the level of awareness of (higher education) faculty and library directors regarding Creative Commons licenses and Open Educational Resources (OER)?

4 What is the level of awareness of (higher education) faculty and library directors regarding Kyrgyz Copyright and Intellectual Property Laws?

5 How potentially helpful do (higher education) faculty and library directors believe libraries could be regarding enabling others' learning regarding Copyright, Creative Commons, and/or Open Educational Resources? 


\section{Method}

An online survey instrument was developed using Qualtrics (see appendix). The mixed methods survey comprised 33 questions to reflect the aims and objectives of the study. In OctoberDecember 2017, the questionnaire was distributed electronically among one hundred and twenty faculty, administrators and librarians employed in higher educational institutions. The survey was available in English and Russian. The overall response rate was of $66.7 \%$.

\section{Results}

\section{Study Participants}

Eighty individuals from nineteen higher education completed portions of the survey. For purposes of the survey, individuals not employed at institutions of higher education and respondents who indicated that they do not teach were removed from the sample before analysis on teaching related topics, resulting in a sample of 35 . The responses of five additional individuals who indicated employment at institutions of higher education but not teaching were included the analysis for the last two topics: awareness, and potential library roles.

Respondents who teach were diversified across various disciplines. Disciplines with four or more respondents included: English language (18\%), Computer Science (9\%), Education/Pedagogy (9\%), Economics, (7\%), and Mathematics (5\%).

While all higher education institution types in Kyrgyzstan were represented, the sample is weighted toward private and intergovernmental institution types and Kyrgyz geographic areas located in the capital and northern part of the country.

\section{Reported use of curriculum materials}

While textbooks as learning resources are a focal point for rural school-level initiatives (World Bank, 2017), higher education respondents indicated using a wide range of learning resources: textbooks, videos or films, audio/sound recordings, literature, workbooks, iTools, books (beyond textbooks), journal articles, and laboratory notebooks in their courses. Little is known about the proportions of use and origin of these media beyond textbooks. For those using textbooks, the age of textbooks is of particular note. Of faculty reporting using a textbook, $56 \%$ indicated it was at least 6 years old. Twenty percent reported using a textbook that was at least 13 years old. This may be a smaller issue for disciplines that change at slower rates, but is a very significant issue given the amount of sociopolitical change Kyrgyzstan has faced in the last ten years, not to mention that physical materials wear out with use.

Textbooks were obtained from many different sources: the institution's library as expected, from the teacher, online, and in some cases students were asked to purchase their own textbooks. Fewer than half of respondents indicated requesting that the library purchase the material. The largest percentage of respondents indicated finding learning material online when asked for titles, some frequent answers revealed freely available online material offered by its producers, such as: "English file" or "Any Logic in 3 days" (English File, n.d.; Grigoryev, 2014). Other specific titles listed were found to be current, in-copyright textbooks whose commercial publishers do not make digital versions freely available and are likely illegally posted. Furthermore, multiple respondents indicated using Internet search engines to locate PDFs of titles or found them in peer-to-peer file sharing systems that redistribute in-copyright materials without permission. 


\section{Teaching practices and pedagogies}

The research question on teaching methods and pedagogies was supported by seven questions. Respondents were asked what they believe are the three most important things they do in the classroom that help students learn. The following methods were cited: interactive strategies applied, situational and problems solving learning methods, group work, real-life examples, and case study or seminar discussions. Several mentioned discipline specific methodologies or theories including: Total physical response, Suggestopedia, and Morphological box thinking, Bloom's taxonomy, PPP (Presentation, Practice, Production), ESA (Engage, Study, Activate), and CLT (Communicative Language Learning). Only one respondent mentioned "lecture" and only one respondent mentioned "tests". Very few mentioned engaging in the process of building or creating something.

We wanted investigate to what degree Soviet-era teacher-centric pedagogy is still in practice. We asked instructors what they believe are the three most important things they currently do in the classroom which help students learn; respondents most frequently cited interactive strategies, applied, situational or problem solving learning methods, group work, real-life examples, and case study or seminar discussions. Only one respondent mentioned "lecture" and only one respondent mentioned "tests." We asked how often they actually utilized particular practices which mapped to teaching styles and teaching style clusters as described by Grasha (1994). Of 27 respondents to the question, six indicated always lecturing and two indicated never lecturing. Using a weighted average, lectures ranked squarely in the middle (17 of 34 practices) with regard to how frequently respondents reported using lecture in class. Still, we found higher average rankings of "expert/formal authority" (Cluster 1) styles than an "expert/facilitator/delegator" teaching style (Cluster 4 practices) encouraged by Grasha (1994).

In the course of the survey we asked whether students were expected to create anything in their courses. Of the 38 respondents, 29 (78.38\%) indicated that they require students to create something in their class. Students reportedly created: presentations, independent projects, student portfolio, term and research projects, problem evaluation and solving, topical analysis, creating [a] real world situation, us[e of] examples from real world sector, individual and group projects. One respondent indicated that students were required to create a 3D Hologram. In subsequent responses it was clear that students created presentations and articles to share at academic competitions and conferences. Other responses indicating that students create, "knowledge, results, ideas, hard work" implied that few faculty asked students to create shareable and real-world artifacts.

Follow up questions asked if instructors provide ways for students to publicly share the work they created. Instructors reported that students shared in class, at seminars, conferences, competitions or in academic journals, suggesting that journal articles are one possible artifact created. Other respondents mentioned sharing via a Gallery Walk, social networks, file sharing services, the course management system, lesson visits, public presentation, and on stage. Institutional repositories often hosted by libraries were not mentioned as a place to share artifacts created as part of a course.

\section{Reported awareness}

We aimed to identify baseline knowledge and level of activity regarding copyright and intellectual property licensing topics in higher education. Ninety six percent of respondents indicated that they had heard of open educational resources and thirty nine percent of respondents indicated that they had used or created "Open Educational Resources". However, when asked about their level of familiarity with the term and use of "Creative Commons licenses" which enable most open educational resources, these numbers dropped significantly: 36\% indicated having never heard of Creative Commons licenses, including seven who had previously indicated having used or adapted/created 
and shared OER. Clearly, for many there is a knowledge gap regarding what makes something an open educational resource, and that free online materials are not necessarily open educational resources. That said, $20 \%$ of respondents indicated that they had heard of Creative Commons licenses and had used some.

When asked about their familiarity with Kyrgyzstan's Copyright law, three quarters of respondents indicated that they have at least general information about Kyrgyz copyright law. Of these, 18 indicated that they provide assistance to others on the topic. Of the $25 \%$ without general information nearly all indicated that they had heard of Kyrgyz Copyright Law but had never tried to find any information about it. Self-reported knowledge about the scope of Kyrgyz Copyright Law varied with 73-90\% of respondents being aware that Kyrgyz Copyright law protects author rights, allows authors to grant rights for others to use their work, and allow educational use of copyrighted works under some conditions.

\section{Perceptions regarding potential library roles}

Part three of the survey aimed to identify current uses of their college or university library by faculty and administrators and whether or not respondents believe that their library could be helpful for learning more about copyright, Creative Commons licenses, and/or open educational resources. Ninety to ninety-seven percent of faculty and administrator respondents indicated that they believe their institution's library can be helpful in learning about these three topics. Respondents offered helpful comments regarding whether comprehensive and reliable information about author rights in Kyrgyzstan is available online, and one noted that "many librarians in Kyrgyzstan are not aware [of] license and authors' rights". Of the 10 academic librarians or academic library directors responding to the survey, two indicated providing assistance to others on copyright topics, two indicated knowing a lot about copyright, and four indicated general awareness of copyright information.

\section{Discussion}

Reported teaching practices were mixed between teacher-centered and student-centered more than we had expected, with "lecture" appearing only half way down the list, and several faculty mentioning student-centric practices such as interactive strategies and references to real-world examples. Taking the first steps to explore and implement open pedagogy may be a challenge for instructors, particularly with its strong emphasis on student agency, active, engaged student learning, the instructor as a "coach," and interaction with curating and creating in the "real world" rather than assignments that mainly the teacher sees. Grasha (1994) notes "...it is not easy [for instructors] to take a less central role and to empower students". A qualitative study covering a broader range of institutions and more inclusive of cultural factors and aspirations of instructors may better reveal the nature, cultural expectations, and incentives around teaching practices in higher education across the country.

While Wikipedia editing has been taught in some professional development settings, the practice of using non-disposable assignments for learning is likely still a new idea for most instructors. Further research is also needed to determine whether additional shareable artifacts such as documents, videos, term papers, short stories, blog posts, or other purposeful and shareable creative works and "non-disposable assignments" (Hendricks, 2015) beyond presentations that are created by students.

Instructors reported using a range of curriculum materials. Of concern and consistent with other research (Muhametjanova \& Cagiltay, 2016) and the authors' prior knowledge is the shortage of recently published learning materials. It would be interesting to further research library budgets 
and roles regarding course materials and faculty awareness thereof. It would also be interesting to hear perceptions of library directors regarding their potential role in the emerging library publishing movements as exemplified by the Library Publishing Coalition (https://librarypublishing.org) and Open Textbook Network Publishing Pilot (2017) and movements to support collaborative faculty publishing such as the Rebus Community (https://about.rebus.community), and the BC Open Campus (Aesoph, 2018). The use, adaptation, and creation of open educational resources may be a sustainable way to build locally derived learning materials that may legally be customized and shared, thus reducing institutional material costs, leveraging instructor and student realworld practice of deeper and higher order learning skills, developing life and work abilities for an increasingly open world.

As the results show, there is a certain degree of awareness of OER and open educational practices among higher educational institutions in Kyrgyzstan. Further education is needed to clearly convey the differences between openly licensed/OER content, content which is in-copyright and free online, and content which is in-copyright and online but likely online illegally.

Most respondents expressed a positive response to the potential of libraries to provide education and guidance regarding Copyright, Creative Commons licenses, and Open Educational Resources. If libraries are to take on providing guidance in these areas, additional professional development and staffing will be needed.

\section{Recommendations}

Fostering collaboration especially among disciplinary and instructor networks among institutions and organizations will bring positive impact on the advancement of OER and open educational practices in the country. Further implementation of open educational practices will depend on continued professional development opportunities, capacity building, institutional support, and relevant training and rewards for those who choose to implement open educational practices. There is a need to address the knowledge gap and misinformed notions regarding the meaning of OER and free online resources, as the latter may substitute for illegally distributed materials. Faculty, librarians, and educational practitioners will require further training and professional development opportunities regarding Creative Commons licenses, and the potential of open educational practices including open pedagogy. Academic libraries can take a lead in promoting OER, Creative Commons and copyright issues, given the librarians have proper training on these topics and practical experience in implementing relevant projects. Finally, OER and open educational practices remain a rich research area for the future, highlighting opportunities for research, development and assessment of open educational practices, analysis of faculty and student preferences regarding reading and teaching using print and electronic formats. Further study is needed regarding the outcomes of current faculty pedagogical practices in parallel with more open educational practices to determine their relevance and value for faculty and students achieving learning goals in varying disciplines and at varying levels of teaching.

\section{Limitations}

Though the survey was targeted to gather countrywide data, the number of participating institutions is insufficient to generalize to all higher education institutions in the country. As most of the respondents were from the institutions located in the capital city and northern part of the country, the survey has limitations in geographical representation. The survey also lacked multiple-choice options in two places which limited the depth of analysis. 


\section{Acknowledgements}

The authors acknowledge support of the U.S. Fulbright Program and U.S. Embassy Bishkek in enabling an April 2017 Fulbright Specialist visit. The authors also wish to recognize the Soros Foundation - Kyrgyzstan for supporting OER initiatives in Kyrgyzstan, and anonymous peer reviewers who provided valuable suggestions.

This paper was presented at the 2018 Open Education Consortium Global Conference, held in Delft (The Netherlands) in April 24th-26th 2018 (https://conference.oeconsortium.org/2018), with whom Open Praxis established a partnership. After a pre-selection by the Conference Committee, the paper underwent the usual peer-review process in Open Praxis.

\section{References}

AUCA News (2017, May 12). Fulbright Specialist Anita Walz Visits AUCA. Retrieved from https:// auca.kg/en/auca_news/3060/

Aesoph, L.M. (2018). Self-Publishing Guide. Victoria, BC: BCcampus. Retrieved from https:// opentextbc.ca/selfpublishguide

Baeten, M., Kyndt, E., Struyven, K., \& Dochy, F. (2010) Using student-centred learning environments to stimulate deep approaches to learning: Factors encouraging or discouraging their effectiveness. Educational Research Review, 5(3), 243-260. https://doi.org/10.1016/j.edurev.2010.06.001

Butcher, N. (2011). A basic guide to Open Educational Resources (OER). Vancouver, Canada: Commonwealth of Learning. Retrieved from http://creativecommons.org/licenses/by-sa/3.0

de la Sablonnière, R., Taylor, D. M., \& Sadykova, N. (2009). Challenges of applying a studentcentered approach to learning in the context of education in Kyrgyzstan. International Journal of Educational Development, 29(6), 628-634. https://doi.org/10.1016/j.ijedudev.2009.01.001

DeRosa, R., \& Jhangiani, R. (2017). Open Pedagogy. In Mays, E. A guide to making open textbooks with students. Retrieved from https://press.rebus.community/makingopentextbookswithstudents/ chapter/open-pedagogy

DeYoung, A. J. (2008). Conceptualizing paradoxes of post-socialist education in Kyrgyzstan. Nationalities Papers, 36(4), 641-657. https://doi.org/10.1080/00905990802230571

DeYoung, A.J. (2013). Redefining students and universities in the Kyrgyz Republic. In Akcali, P. \& Engin-Demir, C. Politics, Identity, and Education in Central Asia. London: Routledge.

Ehlers, U. (2011). Extending the territory: From open educational resources to open educational practices. Journal of Open, Flexible and Distance Learning, 15(2), 1-10. Retrieved from http:// www.jofdl.nz/index.php/JOFDL/article/view/64

EIFL (2017, May 9). Kyrgyzstan Set to Accede to Marrakesh Treaty. Retrieved from http://www.eifl. org/news/kyrgyzstan-set-accede-marrakesh-treaty

English File (n.d.). Oxford University Press. Retrieved from https://elt.oup.com/student/englishfile

European Commission (2012). Higher Education in Kyrgyzstan. [Country report]. Retrieved from http://eacea.ec.europa.eu/tempus/participating_countries/overview/Kyrgyzstan.pdf

Grasha, A. (1994). A Matter of Style: The Teacher as Expert, Formal Authority, Personal Model, Facilitator, and Delegator. College Teaching, 42(4), 142-149. https://doi.org/10.1080/87567555. 1994.9926845

Grigoryev, I. (2014). AnyLogic in Three Days: A Quick Course in Simulation Modeling. Retrieved from https://www.anylogic.com/resources/books/free-simulation-book-and-modeling-tutorials

Hendricks, C. (2015, August 18). Non-disposable assignments in intro to philosophy. You're the teacher [Blog post]. Retrieved from http://blogs.ubc.ca/chendricks/2015/08/18/non-disposableassignments-intro-philosophy

Huitt, W. G., \& Monetti, D. M., (2017). Openness and the transformation of education and schooling. In Jhangiani, R. S. \& Biswas-Diener, R. (eds.) Open: The Philosophy and Practices that 
are Revolutionizing Education and Science (pp. 43-65). London: Ubiquity Press. https://doi. org $/ 10.5334 /$ bbc.d

KyrlibNet (2017). OOR: Novaya Realnost' dlya Vuzov Kyrgyzstana. [Open Educational Resources: New Paradigm for Higher Educational Institutions of Kyrgyzstan]. Retrieved from http://kyrlibnet. $\mathrm{kg} / \mathrm{ru} /$ oor-new/

Masterman, E. (2015). Does an open world need new pedagogies or can existing pedagogies suffice? Proceedings from the European Conference on e-Learning. Kidmore End: Academic Conferences International, Limited.

Merrill, M. C. (2011). Kasha and quality in Kyrgyzstan: Donors, diversity, and dis-integration in higher education. European Education, 43(4), 5-25. https://doi.org/10.2753/EUE1056-4934430401

Morgan, T. (2016, December 21). Open pedagogy and a very brief history of the concept. Explorations in the ed tech world [Blog post]. Retrieved from https://homonym.ca/uncategorized/openpedagogy-and-a-very-brief-history-of-the-concept

Muhametjanova, G., \& Cagiltay, K. (2016). Integrating Technology Into Instruction At A Public University In Kyrgyzstan: Barriers And Enablers. Eurasia Journal of Mathematics, Science and Technology Education, 12(10), 2657-2670. https://doi.org/10.12973/eurasia.2016.1287a

OER Impact Map (2014, July 8). Bishkek Resolution on OER and Digital Education. Retrieved from http://oermap.org/policy/bishkek-resolution-on-oer-and-digital-education

Open Education Consortium (2017) About The Open Education Consortium. Retrieved from http:// www.oeconsortium.org/about-oec

Open Textbook Network (2017). Open Textbook Network Launches The Publishing Cooperative. Retrieved from http://research.cehd.umn.edu/otn/open-textbook-network-launches-the-publishingcooperative-to-support-open-education-expansion/

Smith, M. \& Casserly, C. (2006). The Promise of Open Educational Resources. Change: The Magazine of Higher Learning, 38(5), 8-17. https://doi.org/10.3200/CHNG.38.5.8-17

Soros Kyrgyzstan Foundation News (2017). 19-21 lulya v Naryne Prohodit Letniy Lager' Otkrytyh Obrazovatelnyh Resursov (OOR). [Open Educational Resources Summer Camp to Be Conducted in Naryn, July 19-21]. Retrieved from http://soros.kg/archives/19381

State Service Intellectual Property and Innovation at the Government of the Kyrgyz Republic (2017). The Law of the Kyrgyz Republic "On Copyright and Related Rights". Retrieved from http:// patent.kg/index.php/ru/legislation/67-laws/kodeksy-i-zakony-kyrgyzskoj-respubliki/759-zakonkyrgyzskoj-respubliki-ob-avtorskom-prave-i-smezhnykh-pravakh.html

Strategy for Development of Education in Kyrgyzstan 2012-2020 (2012). Bishkek [in Russian].

UNESCO (2011). CIS on the Way to Open Educational Resources [in Russian]. Retrieved from http:// ru.iite.unesco.org/pics/publications/ru/files/3214683.pdf

V OshGU sostoyalas' presentatsiay proyekta "Otkrytye Yel'skiye kursy" [Open Yale Courses Presented at Osh State University]. (2008, April 30). Retrieved from https://www.turmush.kg/ru/news:15428

World Bank (2017). Project performance assessment report: Kyrgyz Republic-Rural Education Project. Washington, DC: World Bank. Retrieved from http://documents.worldbank.org/curated/ en/246341500307165325/Kyrgyz-Republic-rural-education-project

Wiley, D. (n.d.). Defining the "Open" in open content and open educational resources. Retrieved from http://opencontent.org/definition

Wiley, D. (2017, May 2). OER-enabled pedagogy. Iterating toward openness [Blog post]. Retrieved from https://opencontent.org/blog/archives/5009

WIPO (2017, May 15). Marrakesh Notification No. 29. Retrieved from http://www.wipo.int/treaties/en/ notifications/marrakesh/treaty_marrakesh_29.html

WIPO (n.d.). WIPO Lex. Kyrgyzstan. Retrieved from http://www.wipo.int/wipolex/en/profile. jsp?code=KG 


\section{Appendix: Survey about Open Educational Practices in Kyrgyzstan}

This research study is conducted by Jyldyz Bekbalaeva, Library Director of the American University of Central Asia, and Anita Walz, Fulbright Specialist to the American University of Central Asia from Virginia Tech. The purpose of this study is to understand what curriculum materials and teaching methods are used by higher education faculty in Kyrgyzstan, the level of awareness of higher education faculty and library directors regarding Creative Commons Licenses, Open Educational Resources, Kyrgyz Copyright and intellectual property laws, and to what degree faculty and library directors believe libraries can be helpful in enabling others' learning regarding Copyright, Creative Commons, and open educational resources. This online survey should take you approximately 20 minutes to complete. This survey is voluntary and confidential. Your responses will be accessible only by the research project co-investigators. There may be no direct benefit to you for participating. You will not be paid for your participation. However, findings from this survey will be helpful for developing future library, faculty development, and curriculum resources. Your institute name will be concealed in published research. This precaution is intended to prevent negative repercussions to institutions. This research (\#17-581) is approved by the Institutional Review Board at Virginia Tech. The Institutional Review Board is a group of people that review research studies and protect the rights of people involved in research. If you have questions about your rights as a research subject, please contact IRB Chair, Institutional Review Board Virginia Tech at: [IRB email address].

I am a:

- Librarian

- Faculty member (full time)

- Faculty member (part time)

- Researcher or doctoral student

- Administrator

- Other

Work experience

- Years of experience working at the University level

My institution is:

- American University of Central Asia

- Kyrgyz National University

- Kyrgyz-Turkish Manas University

- International Ataturk-Alatoo University

- Bishkek Humanities University

- Kyrgyz State Pedagogical University

- Kyrgyz Russian-Slavic University

- Krygyz Technical University

- Kyrgyzstan State University of Construction, Transportation and Architecture

- Kyrgyz State Law Academy

- Kyrgyz National Agrarian University

- Kyrgyz State Medical Academy

- Issyk Kul State University

- Jalalbat State University

- Osh State University 
- Talas State University

- Naryn State University

- Batken State University

- University of Central Asia

- Other

My highest diploma or degree is:

- Bachelors

- Masters

- Diploma on Higher Education

- Doctorate (PhD, EdD, MD, JD)

- Other

I teach in the following disciplinary areas (mark all that apply)

- Anthropology

- Agriculture

- Biology

- Business/Finance

- Chemistry

- Communication

- Computer Science

- Economics

- Education/Pedagogy

- Engineering

- Environmental Sciences / Natural Resource Management

- Fine Arts / Design / Theatre

- Geography

- Geology / Geo Sciences

- Government / Political Science

- History

- International Relations

- Journalism

- Language - Russian

- Language - Kyrgyz

- Language - English

- Language - other

- Law

- Mathematics

- Medicine

- Mining

- Music

- Philosophy

- Physics

- Psychology

- Public Administration

- Religion

- Rural / Regional Development

- Sociology

- Statistics 
- Tourism / Leisure Studies

- Other

- I do not teach

\section{TEACHING PRACTICES FOR FACULTY: USE OF PEDAGOGY / METHODOLOGIES}

What do you believe are the three most important things you do in the classroom that help students learn?

In teaching at the college or University level, how often do you use the following teaching methods:

\begin{tabular}{|c|c|c|c|c|c|}
\hline & Always & $\begin{array}{l}\text { Most of } \\
\text { the time }\end{array}$ & $\begin{array}{l}\text { About half } \\
\text { the time }\end{array}$ & Sometimes & Never \\
\hline Lectures & 0 & 0 & 0 & 0 & 0 \\
\hline Term papers & 0 & 0 & 0 & 0 & 0 \\
\hline Tutorials & 0 & 0 & 0 & 0 & $\mathrm{o}$ \\
\hline Guest presentations & 0 & 0 & 0 & 0 & 0 \\
\hline $\begin{array}{l}\text { Video/audio presentations of } \\
\text { content }\end{array}$ & 0 & 0 & 0 & 0 & 0 \\
\hline Guest speakers & 0 & 0 & 0 & 0 & 0 \\
\hline $\begin{array}{l}\text { Teacher-centered class } \\
\text { discussions }\end{array}$ & 0 & 0 & 0 & 0 & 0 \\
\hline Strict standards/requirements & 0 & 0 & 0 & 0 & 0 \\
\hline Grades/tests emphasized & 0 & 0 & 0 & 0 & 0 \\
\hline $\begin{array}{l}\text { Demonstrating ways of } \\
\text { thinking/doing things }\end{array}$ & 0 & 0 & 0 & 0 & 0 \\
\hline Coaching/guiding students & 0 & 0 & 0 & 0 & $\mathrm{o}$ \\
\hline Illustrating alternatives & 0 & 0 & 0 & 0 & 0 \\
\hline Sharing personal viewpoints & 0 & 0 & 0 & 0 & 0 \\
\hline $\begin{array}{l}\text { Sharing thought processes } \\
\text { involved in obtaining answers }\end{array}$ & 0 & 0 & 0 & 0 & 0 \\
\hline $\begin{array}{l}\text { Using personal examples to } \\
\text { illustrate content points }\end{array}$ & 0 & 0 & 0 & 0 & 0 \\
\hline $\begin{array}{l}\text { Having students emulate the } \\
\text { teacher's example }\end{array}$ & 0 & 0 & 0 & 0 & 0 \\
\hline Small group discussion & 0 & 0 & 0 & 0 & 0 \\
\hline
\end{tabular}




Laboratory projects
Instructor-designed group
projects
Student teacher of the day
Self-discovery activities
Learning pairs/debates
Case studies
Role plays/simulations
Problem-based learning
Practicum/guided readings
Student-designed group
projects
Independent study
Independent research projects
Position papers
Student journals
Modular instruction
Self-discovery learning projects
Cooperative learning activities

$\begin{array}{lllll}0 & 0 & 0 & 0 & 0 \\ 0 & 0 & 0 & 0 & 0 \\ 0 & 0 & 0 & 0 & 0 \\ 0 & 0 & 0 & 0 & 0 \\ 0 & 0 & 0 & 0 & 0 \\ 0 & 0 & 0 & 0 & 0 \\ 0 & 0 & 0 & 0 & 0 \\ 0 & 0 & 0 & 0 & 0 \\ 0 & 0 & 0 & 0 & 0 \\ 0 & 0 & 0 & 0 & 0 \\ 0 & 0 & 0 & 0 & 0 \\ 0 & 0 & 0 & 0 & 0 \\ 0 & 0 & 0 & 0 & 0 \\ 0 & 0 & 0 & 0 & 0 \\ 0 & 0 & 0 & 0 & 0 \\ 0 & 0 & 0 & 0 & 0 \\ 0 & 0 & 0 & 0 & 0\end{array}$

What types of learning skills do you ask students in your courses to use? (inside or outside of class) (mark all that apply)

- Memorize and recall (remember)

- Understand complex information (understand)

- Use information in a context different than where it was learned (apply)

- Differentiate between or compare ideas (analyze)

- Critique or defend a decision or position (evaluate)

- Develop or author a new or original work (create)

Do you require students to create anything in your classes?

- Yes

- No

If yes, what do you require students to create in your classes?

If yes, do you provide a way for students to publicaly share what they created in their classes?

- Yes

- No 
If yes, how or where do you provide a place for students to publically share what they created?

\section{USE OF MEDIA / CONTENT}

What types of media or learning resources do you use in your courses?

- Textbooks

- Books (beyond textbooks)

- Journal articles

- Newspaper articles

- Videos or films

- Audio or sound recordings

- Podcasts

- Workbooks

- Laboratory notebooks

- Other

What is the publication year(s) of the textbooks you are using?

- Earlier than 2000

- 2000-2004

- $2005-2010$

- 2011-2017

- I don't use any textbooks.

In what language(s) are the textbooks written?

- Russian

- Kyrgyz

- Turkish

- English

- Other

Where do textbooks for your class come from?

- Provided by the college or university library

- I find textbooks online

- I use my own materials

- Students buy their textbooks

- I don't use any textbooks

- Other

Do you use textbooks you find online for free?

- Yes

- No

What are the titles of the textbooks you find online for free? 
Please list the website or URL where you located the free online textbook(s):

Do you assign students to use these textbooks that you find free online?

- Yes

- No

How do you direct students to these materials?

- I email a PDF of the textbook to the students.

- I email a URL of the textbook to the students.

- I upload a PDF or file to a computer or computer system at my college or university.

- I explain to students during class how to find these materials.

- I ask students to tell other students how to find the textbook(s).

- I print out a hard copy for students' use.

- I request that the library purchase a copy for student use.

- Other

\section{AWARENESS OF OPEN EDUCATIONAL RESOURCES}

How familiar are you with the following terms?

How familiar are you with the following term: Open Educational Resources

- l've never heard of this

- I've heard of this but never looked for any

- I've heard of this but never used any

- I've heard of this and have used some

- I've heard of this and have adapted or created and shared some.

How familiar are you with the following term: Creative Commons licenses

- I've never heard of this.

- I've heard of this but never looked for any.

- I've heard of this but never used any.

- I've heard of this and have used some.

- I've heard of this and have adapted or created and shared some.

\section{AWARENESS OF KYRGYZ COPYRIGHT LAW}

How familiar are you with Kyrgyzstan's Copyright law?

- l've never heard of this

- I've heard of this but never tried to find any information on this.

- I've heard of this and know general information regarding Kyrgyz copyright.

- I've heard of this and know a lot about this topic.

- I've heard of this and provide assistance to others regarding this topic. 
Are you aware that Kyrgyz Copyright law:

\begin{tabular}{l|cc} 
& Yes & No \\
\hline Protects author rights & 0 & 0 \\
Allows authors to grant rights for others to use their work? & 0 & 0 \\
$\begin{array}{l}\text { Allows educational use of copyrighted works under some } \\
\text { conditions? }\end{array}$ & 0 & 0
\end{tabular}

\section{PERCEPTION OF LIBRARY POTENTIAL HELPFULNESS}

Do you use your institution's library?

- Yes

- No

For what purposes do you use your institution's library?

- I get books or textbooks

- I can recommend the library acquire books and textbooks

- I use electronic databases and resources

- I obtain journal articles from the library

- I use library services such as reference, research help, or interlibrary loan

- I invite librarians to do a workshop for my students

- I use other library help

Do you think your institution's library can be helpful to learn more about copyright?

- Yes

- No

- Don't know

Do you think your institution's library can be helpful to learn more about open licenses or Creative Commons?

- Yes

- No

- Don't know

Do you think your institution's library can be helpful to learn more about open educational resources?

- Yes

- No

- Don't know

\section{ADDITIONAL COMMENTS OR QUESTIONS}

What other comments or questions do you have about topics covered in this survey? 